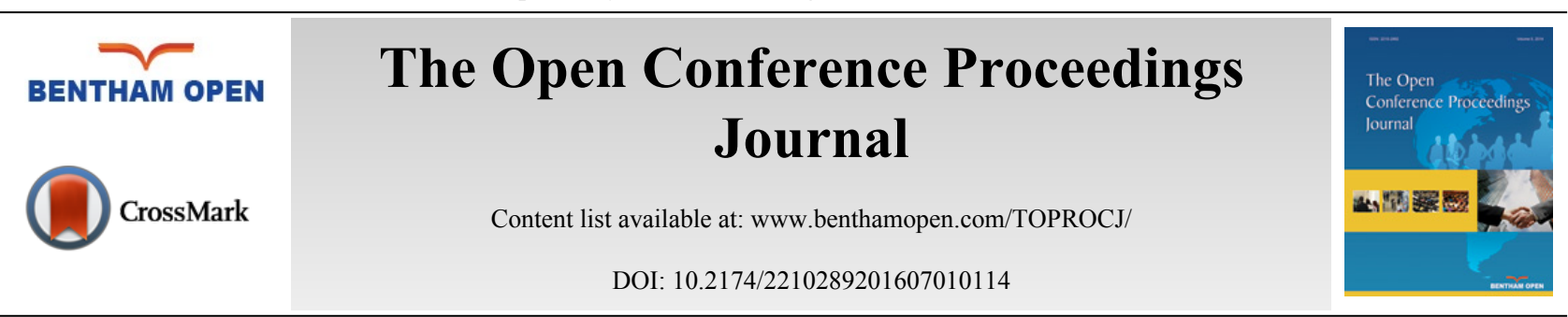

\title{
Formulation and In-Vitro Evaluation of Controlled Release Matrix Tablets of Diltiazem Hydrochloride Using Different Rate Controlling Polymers
}

\author{
Ghulam Razaque ${ }^{1}$, Gul M. Khan², Muhammad Z. Danish", ${ }^{3, *}$ Shafi Muhammad, Nisar A. Shahwani', \\ Kamran A. Khan ${ }^{4}$, Nayab B. Rizvi ${ }^{5}$ and Muhammad Younis ${ }^{1}$ \\ ${ }^{I}$ Faculty of Pharmacy, University of Balochistan, Quetta, Pakistan \\ ${ }^{2}$ Department of Pharmacy, Quaid-i-Azam University, Islamabad 45320, Pakistan \\ ${ }^{3}$ Department of Pharmaceutics, University College of Pharmacy, University of Punjab, Lahore, Pakistan \\ ${ }^{4}$ Department of Pharmaceutics, Faculty of Pharmacy, Gomal University, D.I. Khan, K.P.K, Pakistan \\ ${ }^{5}$ Institute of Chemistry, University of the Punjab, Lahore, Pakistan
}

Received: September 8, 2015

Revised: January 18,2016

Accepted: January 20, 2016

\begin{abstract}
In present study, directly compressed controlled released matrix tablets of Diltiazem Hydrochloride were formulated at drug-to-polymer ratios (D: P) of 10:1, 10:2, 10:3 using polymers Ethocel 45 Premium, K100 LV Methocel, K15M EP Premium Methocel as rate controlling agents. In some formulations of Diltiazem hydrochloride and Ethocel 45 Premium matrices, $30 \%$ of filler was replaced by Co-excipient like HPMC, CMC-Na and Starch. The in vitro dissolution studies were performed according to USP Method-I (rotating basket method). Phosphate buffer ( $\mathrm{pH}$ 7.4) was used as dissolution medium and the rotation speed of baskets were kept constant at 100rpm and temperature of the medium was maintained at $37 \pm 0.1{ }^{\circ} \mathrm{C}$. In order to determine the drug release kinetics various models such as Ist-order, Zero-order, Hixon Crowell, Highuchi and Power Law were applied. Herbesser ${ }^{\circledR}$ tablets were used as reference standard for comparison of dissolution profiles of standard and tests formulation by applying difference factor $\left(f_{1}\right)$ and similarity factor $\left(f_{2}\right)$. The rate controlling agents extended the drug release rates but Ethocel 45 Premium extended more efficiently than the K100 LV Methocel and K15M EP Premium Methocel containing matrices. These newly prepared formulations released the drug mostly by anomalous non Fickian drug diffusion. The drug release profiles of the test formulations were different from the drug release profile of reference standard formulation (Herbesser ${ }^{\circledR}$ tablets). The Co-excipients increased the drug released from the matrices containing Ethocel 45 premiums. Ethocel 45 Premium, K100 LV Methocel and K15M EP Premium Methocel can be effectively used as rate controlling agents in formulation of directly controlled release matrix tablets.
\end{abstract}

Keywords: Co-excipients, Diltiazem Hydrochloride, Ethocel 45 Premium, K100 LV Methocel, K15M EP Premium Methocel.

\section{INTRODUCTION}

In the recent years, drug delivery systems (DDS) have brought revolution from simple pills to the more sophisticated controlled release dosage forms. Their systemic non-specificity has also been turned into organ and celltarget-specific systems [1]. Through extended release dosage forms, it is possible to achieve therapeutic plasma levels of the drug with short half-life for prolonged period of time [2]. Controlled release DDS release drug at rates, which are significantly different from conventional dosage forms [3]. The controlled release dosage forms are designed to control the rate of drug delivery, target the delivery of the drug to a tissue and/or maintain the duration of therapeutic efficacy. Drug release from controlled release dosage form has predictability, reproducibility [4] while the conventional dosage forms release the drug by dissolution or diffusion. Thus in conventional systems amount of drug fluctuates in plasma

\footnotetext{
* Address correspondence to this author at the Department of Pharmaceutics, University College of Pharmacy, University of Punjab, Lahore, Pakistan; Tel: 0092-321-4041222; Email: pfarmacist@hotmail.com
} 
and may cause many side effects [5]. For controlled release oral preparations, formulation of drug embedded matrix is one of the least complicated and commercially used approaches [6]. Ethocel is used as matrix forming agent in the designing of controlled release matrix tablets and microcapsules development [7]. Diltiazem $\mathrm{HCl}$ is the inhibitor of cellular influx of calcium ion. Diltiazem $\mathrm{HCl}$ is an antihypertensive agent which is widely used in the treatment of hypertension and angina [8]. It also inhibits ergonovine-induced and spontaneous coronary artery spasms [9]. The main objective of the present study was the development of once a day controlled release matrix tablets of Diltiazem $\mathrm{HCl}$ with Ethocel 45 Premium, K100 LV Methocel and K15M EP Premium Methocel as rate controlling agents. The matrices were prepared by direct compression method. The polymers extended the drug release rate, moreover Ethocel 45 Premium further extended the drug release rates as compared to other polymers used in this study. These controlled release matrices might reduce dosing frequency and enhance patient's compliance.

\section{MATERIALS AND METHODS}

\subsection{Chemicals Used}

All chemicals including Diltiazem.HCl (Drug testing laboratory, Peshawar), lactose, magnesium stearate (BDH Chemical Ltd, Pool England), Ethocel standard 45 Premium, K100LV Methocel, K15M EP Premium Methocel (Dow Chemical Co, Midland USA), sodium hydroxide (Merk, Germany), Monobasic potassium phosphate, Herbesser (Highnoon Laboratories Ltd), Methocel K100LV, Starch and CMC (Merk, Germany) and others were of analytical grade.

\subsection{Instruments Used}

UV-Visible Spectrophotometer Model No. 1610 (Shimadzu, Japan), Electronic Balance (Shimadzu, Japan), pHmeter (Denver, USA), Syringes (Otsuka Pakistan), Pharma Test Dissolution Apparatus (Germany) Beakers, Test tubes and Volumetric Flasks (Pyrex, Japan), Friabilator (Erweka, Germany), Single Punch Machine (Erweka GMBH, Germany), Vernier caliper (Germany) and Hardness tester (Erweka, German).

\subsection{Analytical Curve of Diltiazem Hydrochloride}

Stock solution was prepared by dissolving $20 \mathrm{mg}$ of Diltiazem Hydrochloride in $100 \mathrm{ml}$ of phosphate buffer $(7.2 \mathrm{pH})$. $50 \mathrm{ml}$ from stock solution was taken and diluted to $100 \mathrm{ml}$ with the buffer solution and obtained the first dilution containing $0.05 \mathrm{mg}$ of Diltiazem Hydrochloride. The same way dilutions containing $0.025 \mathrm{mg} / \mathrm{ml}, 0.0125 \mathrm{mg} / \mathrm{ml}$ and $0.00625 \mathrm{mg} / \mathrm{ml}$ of Diltiazem Hydrochloride were prepared. These dilutions were analyzed spectrophotometrically at wave length of $294.5 \mathrm{~nm}$.

\subsection{Solubility Studies}

$50 \mathrm{mg}$ of Diltiazem Hydrochloride was taken $50 \mathrm{ml}$ volumetric flasks. The solvents such as Phosphate buffer (pH 6.8 and $\mathrm{pH}$ 7.4) and distilled water were added. The volumetric flasks were placed for $24 \mathrm{hrs}$ in shaker at three different temperature conditions $\left(25^{\circ} \mathrm{C}, 37^{\circ} \mathrm{C}\right.$ and $\left.40^{\circ} \mathrm{C}\right)$.

\subsection{Formulation of Diltiazem Hydrochloride Matrix Tablets}

Each of the 100mg tablet was containing 30mg of the drug, polymers; Ethocel 45 Premium or K100 LV Methocel or K15M EP Premium (D: P of 10:1, 10:2 and 10:3), magnesium stearate (0.5\%), and spray dried lactose (filler) were added as shown in Tables 1-3. Formulations containing Ethocel 45 Premium with Co-excipients such as HPMC or CMC or Starch (30\% of filler) are shown in Table 4.

Table 1. Composition of $100 \mathrm{mg}$ diltiazem hydrochloride and ethocel 45 premium matrix tablets.

\begin{tabular}{|c|c|c|c|c|}
\hline Drug to Polymer Ratio & Drug Diltiazem Hydrochloride & $\begin{array}{c}\text { Polymers Ethocel 45 } \\
\text { Premium }\end{array}$ & $\begin{array}{c}\text { Lubricant Magnesium Stearate } \\
\mathbf{( 0 . 5 \% )}\end{array}$ & Filler (Lactose) \\
\hline $10: 1$ & $30 \mathrm{mg}$ & $3 \mathrm{mg}$ & $0.5 \mathrm{mg}$ & $66.5 \mathrm{mg}$ \\
\hline $10: 2$ & $30 \mathrm{mg}$ & $6 \mathrm{mg}$ & $0.5 \mathrm{mg}$ & $63.5 \mathrm{mg}$ \\
\hline $10: 3$ & $30 \mathrm{mg}$ & $9 \mathrm{mg}$ & $0.5 \mathrm{mg}$ & $60.5 \mathrm{mg}$ \\
\hline
\end{tabular}


Table 2. Composition of 100mg diltiazem hydrochloride and K100 LV Methocel matrix tablets.

\begin{tabular}{|c|c|c|c|c|}
\hline Drug to Polymer Ratio & Drug Diltiazem Hydrochloride & Polymer K100 LV Methocel & $\begin{array}{c}\text { Lubricant Magnesium Stearate } \\
\mathbf{( 0 . 5 \% )}\end{array}$ & Filler (Lactose) \\
\hline $10: 1$ & $30 \mathrm{mg}$ & $3 \mathrm{mg}$ & $0.5 \mathrm{mg}$ & $66.5 \mathrm{mg}$ \\
\hline $10: 2$ & $30 \mathrm{mg}$ & $6 \mathrm{mg}$ & $0.5 \mathrm{mg}$ & $63.5 \mathrm{mg}$ \\
\hline $10: 3$ & $30 \mathrm{mg}$ & $9 \mathrm{mg}$ & $0.5 \mathrm{mg}$ & $60.5 \mathrm{mg}$ \\
\hline
\end{tabular}

Table 3. Composition of 100mg diltiazem hydrochloride and K15M EP premium methocel matrix tablets.

\begin{tabular}{|c|c|c|c|c|}
\hline Drug to Polymer Ratio & Diltiazem Hydrochloride & K15M EP Premium Methocel & Lubricant Magnesium Stearate (0.5\%) & Filler (Lactose) \\
\hline $10: 1$ & $30 \mathrm{mg}$ & $3 \mathrm{mg}$ & $0.5 \mathrm{mg}$ & $66.5 \mathrm{mg}$ \\
\hline $10: 2$ & $30 \mathrm{mg}$ & $6 \mathrm{mg}$ & $0.5 \mathrm{mg}$ & $63.5 \mathrm{mg}$ \\
\hline $10: 3$ & $30 \mathrm{mg}$ & $9 \mathrm{mg}$ & $0.5 \mathrm{mg}$ & $60.5 \mathrm{mg}$ \\
\hline
\end{tabular}

Table 4. Composition of 100mg diltiazem hydrochloride and ethocel 45 premium matrix tablets having co-excipients (Starch or HPMC or Na-CMC).

\begin{tabular}{|c|c|c|c|c|c|}
\hline $\begin{array}{c}\text { Drug to Polymer } \\
\text { Ratio }\end{array}$ & Diltiazem Hydrochloride & $\begin{array}{c}\text { Polymers Ethocel 45 } \\
\text { Premium }\end{array}$ & $\begin{array}{c}\text { Co-excipients (Starch or } \\
\text { HPMC or Na-CMC) }\end{array}$ & $\begin{array}{c}\text { Lubricant Magnesium } \\
\text { Stearate (0.5\%) }\end{array}$ & Filler (Lactose) \\
\hline $10: 1$ & $30 \mathrm{mg}$ & $3 \mathrm{mg}$ & $21.39 \mathrm{mg}$ & $0.5 \mathrm{mg}$ & $46.55 \mathrm{mg}$ \\
\hline $10: 2$ & $30 \mathrm{mg}$ & $6 \mathrm{mg}$ & $19.05 \mathrm{mg}$ & $0.5 \mathrm{mg}$ & $44.45 \mathrm{mg}$ \\
\hline $10: 3$ & $30 \mathrm{mg}$ & $9 \mathrm{mg}$ & $18.15 \mathrm{mg}$ & $0.5 \mathrm{mg}$ & $42.35 \mathrm{mg}$ \\
\hline
\end{tabular}

\subsection{Preparation of Diltiazem Hydrochloride Matrix Tablets}

The ingredients were mixed at D: P ratio of 10:1, 10:2, 10:3, and then filler was added. In the tablets containing Ethocel 45 Premium, the co-excipient was also added and passed through mesh \#30; this sieving was repeated twice after adding $0.5 \% \mathrm{w} / \mathrm{w}$ magnesium stearate. After mixing, direct compression method was used for the preparation of tablets through single punch machine (Erweka, Germany).

\subsection{Physical Characterization of Diltiazem Hydrochloride Matrices}

Physical characteristics including hardness, friability and dimension (thickness and diameter) of the controlled release matrix tablets were determined according to the USP acceptable ranges.

\subsection{In-Vitro Dissolution Study of Diltiazem Hydrochloride Matrix Tablets}

Dissolution studies were performed according to USP Method-I (Rotating Basket Method). The 8-station apparatus was used Pharma Test dissolution apparatus (Hunburg, Germany). Each station was filled with $900 \mathrm{ml}$ of $0.2 \mathrm{M}$ phosphate buffer ( $\mathrm{pH}$ 7.4) as dissolution medium. The rotation of basket was 100rpm and temperature was maintained at $37 \pm 0.1 \mathrm{C}$. The $5 \mathrm{ml}$ samples were collected at specific time intervals. The samples were analyzed by using UVVisible Spectrophotometer UV-1601 (Shimadzu, Japan) at $294.5 \mathrm{~nm}$. Percentage release was estimated from analytical curve of the drug.

\subsection{Investigation of Drug Release Kinetics of Diltiazem Hydrochloride from Matrix Tablets}

The following mathematical models were used to analyze the drug release kinetics from newly prepared formulations as given in Table $\mathbf{5}$.

Table 5. Indicating kinetic models applied.

\begin{tabular}{|c|c|}
\hline Zero-order Kinetics [10] & $\mathrm{W}=\mathrm{k}_{1} \mathrm{t}$ Eq 1 \\
\hline First-order Kinetics [10] & $\ln (100-\mathrm{W})=\ln 100-\mathrm{k}_{2} \mathrm{t}$ Eq 2 \\
\hline Hixon Crowel's (erosion model) [10] & $(100-\mathrm{W})^{1 / 3}=100^{1 / 3}-\mathrm{k}_{3} \mathrm{t} \mathrm{Eq} 3$ \\
\hline Higuchi's (diffusion model) [11] & $\mathrm{W}=\mathrm{k}_{4} \mathrm{t}^{1 / 2} \mathrm{Eq} 4$ \\
\hline Power Law (diffusion/relaxation model) [12] & $\mathrm{M}_{\mathrm{t}} / \mathrm{M}_{\infty}=\mathrm{k}_{5} \mathrm{t}^{\mathrm{n}} \mathrm{Eq} 5$ \\
\hline
\end{tabular}


Where, $W$ represents $\%$ drug release at time $t, k_{1}-k_{4}$ is rate constants. $M_{t} / M_{\infty}$ shows the fractional of drug released in the dissolution medium. The $\mathrm{k}_{5}$ is a constant integrates the geometric and structural characteristic of matrix. Where $\mathrm{n}$, is a diffusion exponent characterizes the mechanism of drug release. If $n=0.5$, drug exhibits Quasi-Fickian diffusion mechanism for transport through polymeric matrix. If $n>0.5$ and if $n=1$ the mechanism is anomalous, non-Fickian and non-Fickian, Case II or Zero order release, respectively [13].

\subsection{Applying Difference Factor $\left(f_{1}\right)$ and Similarity Factor $\left(f_{2}\right)$}

Difference factor $\left(f_{1}\right)$ and similarity factor $\left(f_{2}\right)$ were used to determine the dissolution profiles equivalency or difference between tests and reference formulation (Herbesser ${ }^{\circledR}$ Conventional Tablets)

$$
\mathrm{f}_{2}=50 \log \left\{\left[1+1 / \mathrm{n} \mathrm{W}_{\mathrm{t}} \sum_{\mathrm{t}=1}^{\mathrm{n}}\left(\mathrm{R}_{\mathrm{t}}{ }^{\mathrm{n}}{ }_{\mathrm{t}=1}\left(\mathrm{R}_{\mathrm{t}}-\mathrm{T}_{\mathrm{t}}\right)^{2}\right]^{-0.5} \times 100\right\}\right.
$$

Where $n$ shows number of pull points, $W_{t}$ is optional weight factor, $R_{t}$ is reference profile at time point $t$ and $T_{t}$ is test profile at same time point. The FDA has given if dissolution profile ranges from 50-100 which indicates dissolution profile equivalency [14].

$$
f 1=\left\{\frac{\sum_{t-1}^{n}\left|R_{t}-T_{t}\right|}{\sum_{t-1}^{n} R_{t}}\right\} * 100
$$

The range of difference factor $\mathrm{f}_{1}$ is $1-15$ shows dissimilarity.

\section{Results and Discussion}

\subsection{Analytical Curve}

The standard regression value for Diltiazem HCl obtained was; $y=3.4464 x+0.0005$ with the regression coefficient $\left(\mathrm{R}^{2}\right)$ of 0.9998 . This indicates direct relationship between the concentration and absorbance. The results are shown in Table 6 and Fig. (1).

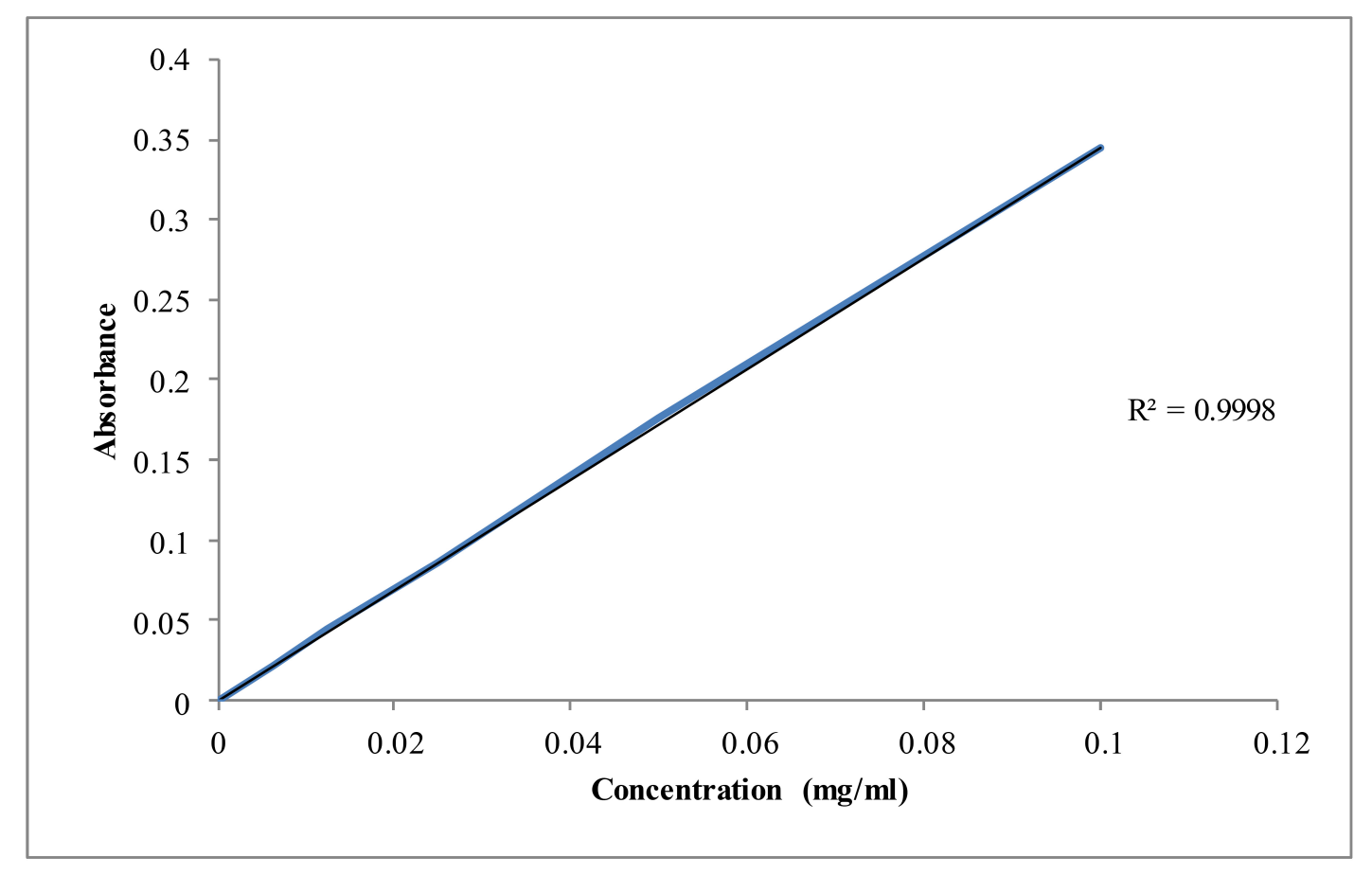

Fig. (1). Diltiazem hydrochloride standard curve. 
Table 6. Diltiazem Hydrochloride stock solution and dilutions absorbances and concentrations.

\begin{tabular}{|c|c|c|c|c|c|}
\hline S. No & conc. $(\mathbf{m g} / \mathbf{m l})$ & abs(1) & abs(2) & abs(3) & Average abs \\
\hline 1 & 0.00625 & 0.021 & 0.022 & 0.023 & 0.022 \\
\hline 2 & 0.0125 & 0.045 & 0.044 & 0.043 & 0.044 \\
\hline 3 & 0.025 & 0.086 & 0.085 & 0.084 & 0.085 \\
\hline 4 & 0.05 & 0.174 & 0.176 & 0.178 & 0.176 \\
\hline 5 & 0.1 & 0.344 & 0.343 & 0.345 & 0.344 \\
\hline
\end{tabular}

\subsection{Solubility Studies}

The results of solubility studies are given in Table 7. It shows that Diltiazem Hydrochloride is free soluble in phosphate buffer ( $\mathrm{pH} 7.4)$ at $37^{\circ} \mathrm{C}$.

Table 7. Results of Solubility studies of Diltiazem Hydrochloride.

\begin{tabular}{|c|c|c|c|}
\hline S. No & Solvent & Temperature & Solubility \\
\hline $\mathbf{1}$ & Phosphate buffer $(6.8 \mathrm{pH})$ & $2{ }^{\circ} \mathrm{C}$ & $0.8 \mathrm{mg} / \mathrm{ml}$ \\
\hline $\mathbf{2}$ & Phosphate buffer $(6.8 \mathrm{pH})$ & $37^{\circ} \mathrm{C}$ & $0.86 \mathrm{mg} / \mathrm{ml}$ \\
\hline $\mathbf{3}$ & Phosphate buffer $(6.8 \mathrm{pH})$ & $40{ }^{\circ} \mathrm{C}$ & $0.89 \mathrm{mg} / \mathrm{ml}$ \\
\hline $\mathbf{4}$ & Phosphate buffer $(7.4 \mathrm{pH})$ & $2{ }^{\circ} \mathrm{C}$ & $0.98 \mathrm{mg} / \mathrm{ml}$ \\
\hline $\mathbf{5}$ & Phosphate buffer $(7.4 \mathrm{pH})$ & $37{ }^{\circ} \mathrm{C}$ & $1 \mathrm{mg} / \mathrm{ml}$ \\
\hline $\mathbf{6}$ & Phosphate buffer $(7.4 \mathrm{pH})$ & $40{ }^{\circ} \mathrm{C}$ & $1 \mathrm{mg} / \mathrm{ml}$ \\
\hline $\mathbf{7}$ & Distilled Water & $25^{\circ} \mathrm{C}$ & $0.986 \mathrm{mg} / \mathrm{ml}$ \\
\hline $\mathbf{8}$ & Distilled Water & $37^{\circ} \mathrm{C}$ & $0.987 \mathrm{mg} / \mathrm{ml}$ \\
\hline $\mathbf{9}$ & Distilled Water & $40^{\circ} \mathrm{C}$ & $0.99 \mathrm{mg} / \mathrm{ml}$ \\
\hline
\end{tabular}

\subsection{Physical Characterization of Compressed Diltiazem Hydrochloride CR Tablets}

The results of physical tests employed for the formulations are given in the Table $\mathbf{8}$. Thickness of controlled release matric tablets ranged from 2.6-2.9 mm and diameter was $8 \mathrm{~mm}$. The hardness was found in range of $6-7 \mathrm{~kg} / \mathrm{cm}^{2}$, these all values were within the acceptable USP ranges. The average weight loss of tablets after friability test was $0.08-0.23 \%$, which is within the acceptable USP range. All the formulations which contained Diltiazem Hydrochloride and Ethocel Standard 7 FP, K100 LV Methocel, K15M EP Methocel Premium and Ethocel Standard 45 Premium having Co-excipients (Starch or HPMC or Na-CMC) were more compressible hence it produced harder tablets. These results are consistent with findings of Khan and Meidan [15] that Ethocel produces formulations with good compressibility and hardness.

Table 8. Results of physical tests applied.

\begin{tabular}{|l|c|c|c|c|}
\hline \multicolumn{1}{|c|}{ Formulations } & $\begin{array}{c}\text { Thickness } \\
(\mathbf{m m})\end{array}$ & $\begin{array}{c}\text { Diameter } \\
(\mathbf{m m})\end{array}$ & $\begin{array}{c}\text { Hardness } \\
\left(\mathbf{k g} / \mathbf{c m}^{2}\right)\end{array}$ & $\begin{array}{c}\text { Friability } \\
(\mathbf{\%})\end{array}$ \\
\hline Diltiazem Hydrochloride and Ethocel 45Premium & $2.6 \pm 0.06 \mathrm{~mm}$ & $8.0 \mathrm{~mm}$ & $6.5 \pm 0.05$ & $0.08 \% \pm 0.18$ \\
\hline Diltiazem Hydrochloride and K100 LV Methocel & $2.7 \pm 0.12 \mathrm{~mm}$ & -do- & $6.98 \pm 0.13$ & $0.16 \% \pm 0.03$ \\
\hline Diltiazem Hydrochloride and K15M EP Methocel Premium & $2.8 \pm 0.07 \mathrm{~mm}$ & -do- & $6.82 \pm 0.24$ & $0.18 \% \pm 0.06$ \\
\hline Diltiazem Hydrochloride and Ethocel 45Premium with Co-excipient (Starch) & $2.7 \pm 0.09 \mathrm{~mm}$ & -do- & $6.79 \pm 0.09$ & $0.21 \% \pm 0.23$ \\
\hline Diltiazem Hydrochloride and Ethocel 45Premium with Co-excipient (Na-CMC) & $2.8 \pm 0.21 \mathrm{~mm}$ & -do- & $6.86 \pm 0.018$ & $0.23 \% \pm 0.09$ \\
\hline Diltiazem Hydrochloride and Ethocel 45Premium with Co-excipient (HPMC) & $2.9 \pm 0.15 \mathrm{~mm}$ & -do- & $7.0 \pm 0.02$ & $0.19 \% \pm 0.12$ \\
\hline
\end{tabular}

\subsection{Drug Release Patterns}

The drug release profiles of Diltiazem Hydrochloride with polymers in comparison with its conventional formulations are shown in (Figs. 2-4). The release studies of drug were obtained in time intervals i.e., 0.5, 1.0, 1.5, 2.0, $3.0,4.0,5.0,6.0,8.0,10,12,18$ and 24 hours and drug release calculated from standard curve of Diltiazem Hydrochloride. The controlled release matrix tablets with polymer (Ethocel Standard 45 Premium) tablets (D: P ratio of $10: 1$ ) released $86 \%$ of drug, $84 \%$ at D: P ratio of $10: 2$ and $81 \%$ at D: P ratio of $10: 3$ after 24 hours. Tablets with polymer 
(K100 LV Methocel) at D: P ratio of 10:1, 10:2 and 10:3) released 96\%, 93\% and 91\% respectively after 24 hours. Tablets with polymer (K15M EP Methocel Premium) at D: P ratios of 10:1, 10:2 and 10:3 released 95\%, 94\% and 90\%, respectively. The release profile of reference standard (Herbesser ${ }^{\circledR}$ tablets) was $97 \%$ after 1 hour and was same after 24 hours. The Ethocel Standard 45 Premium extended the release rates of the active ingredient because of its better compressibility which confirms the findings of Khan and Meidan [15]. K100 LV Methocel and K15M EP Methocel Premium also prolonged release of drug from matrices because of formation of gel around tablet during dissolution. This result also confirms the earlier results of other authors [15] that HPMC forms a gel layer on the surface of tablet and releases the drug through diffusion.

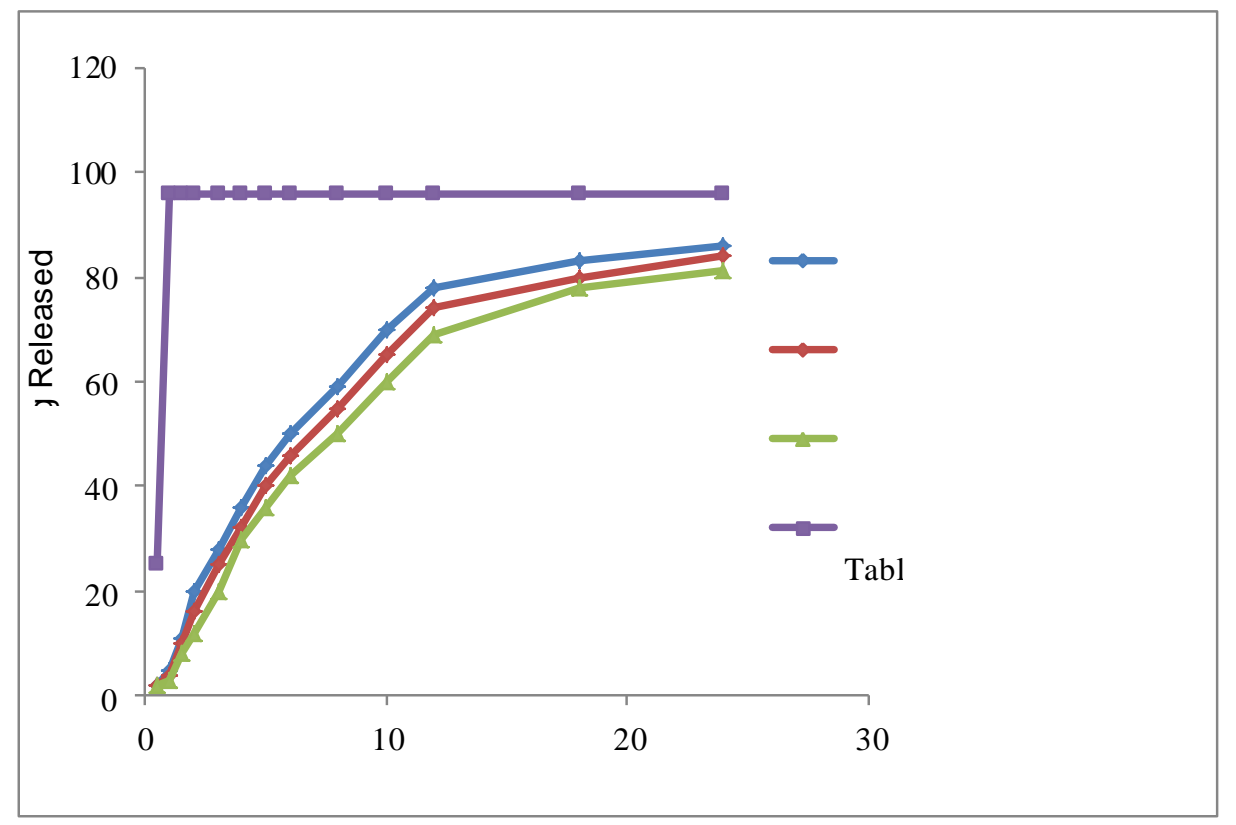

Fig. (2). Diltiazem Hydrochloride release profile from directly compressed matrices of Ethocel 45 Premium at Drug to Polymer (D: P) of 10:1, 10:2 and 10:3 and Herbesser ${ }^{\circledR}$ Conventional Tablets.

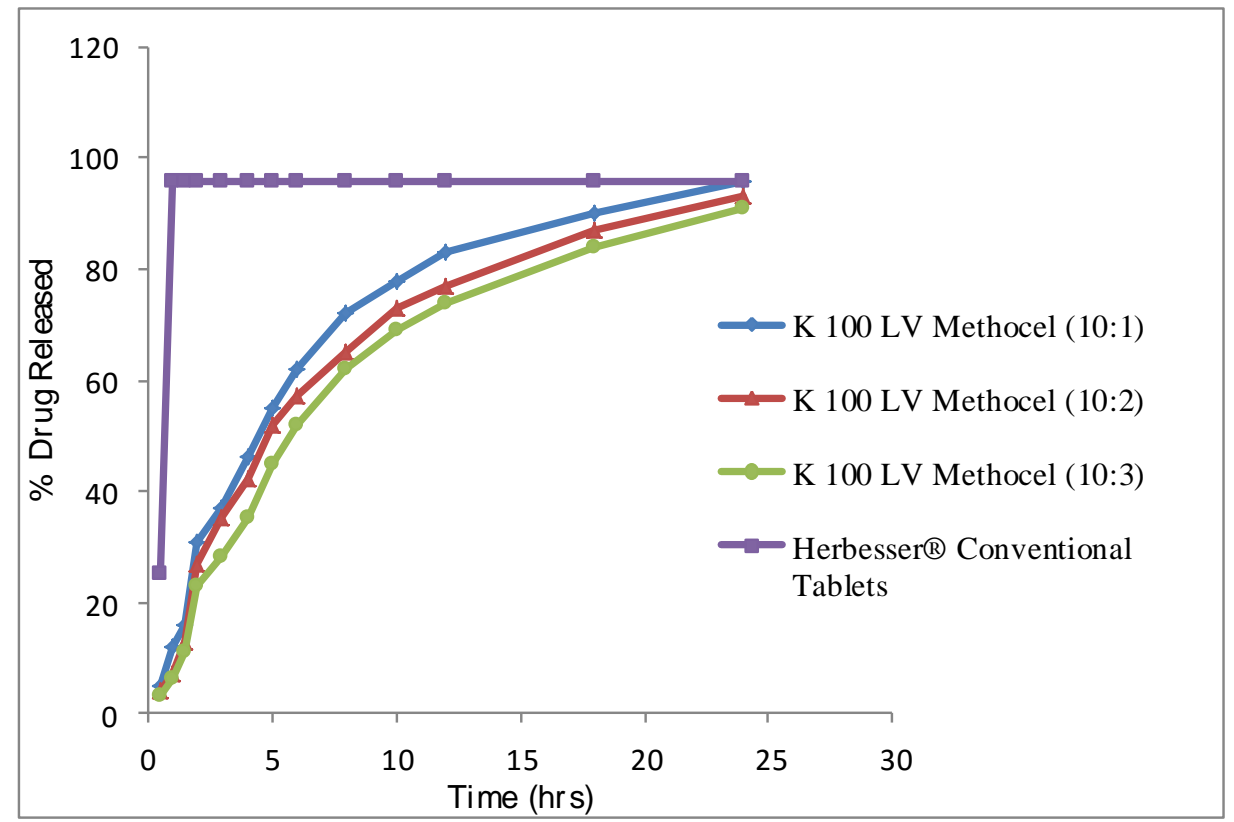

Fig. (3). Diltiazem Hydrochloride release profile from directly compressed matrices of K 100 LV Methocel at Drug to Polymer (D: P) of 10:1, 10:2 and 10:3 and Herbesser ${ }^{\circledR}$ Conventional Tablets. 


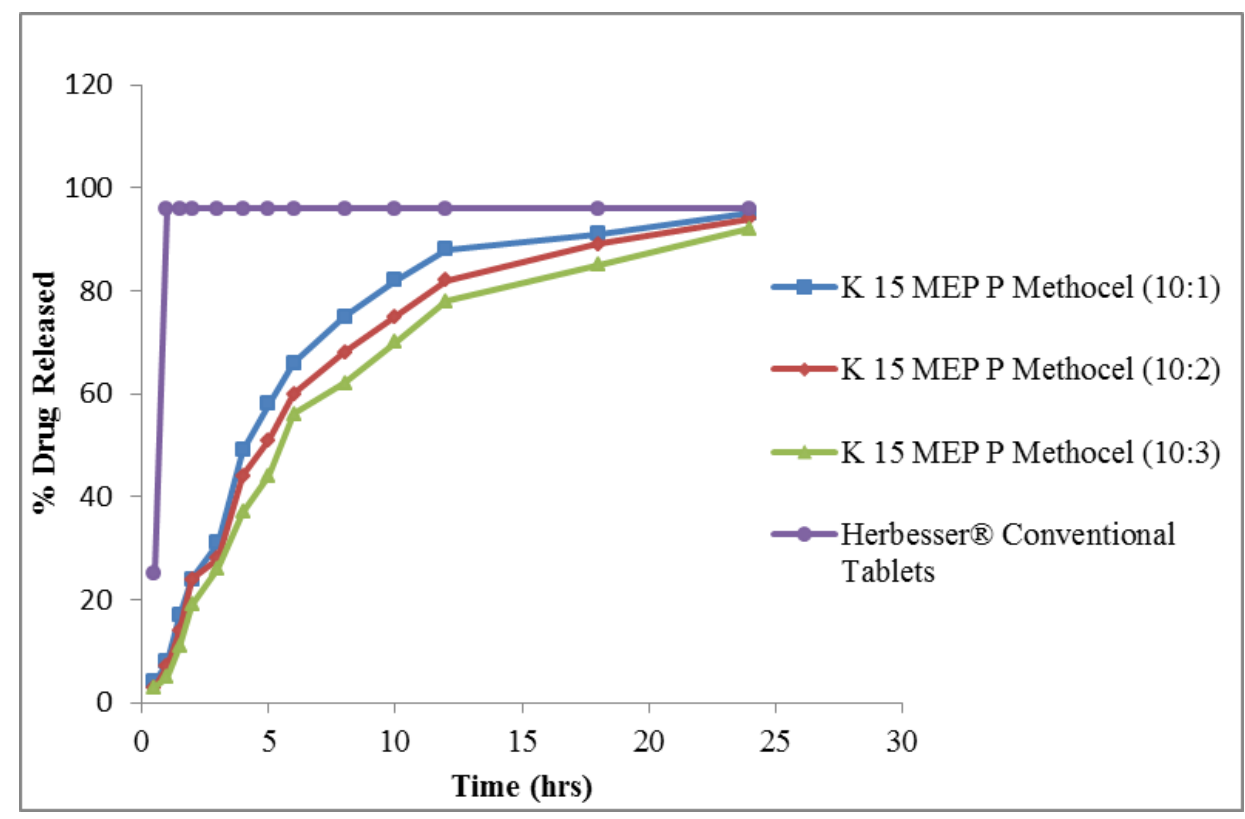

Fig. (4). Diltiazem Hydrochloride release profile from directly compressed matrices of K 13 MEP P Methocel at Drug to Polymer (D: P) of 10:1, 10:2 and 10:3 and Herbesser ${ }^{\circledR}$ Conventional Tablets.

\subsection{Effect of HPMC}

The controlled release tablets with Ethocel Standard 45 Premium, 30\% of HPMC were used in place of spray dried lactose. The controlled release tablets at D: P ratios of 10:1, 10:2, and 10:3 released 97\%, 96\% and 94\% respectively in 12 hours, and the results are as given in Fig. (5). HPMC absorbs water and dissolves leading to increased osmotic forces within the matrices thereby might enhance the drug release and is in conformity with the results of other authors; [16 19] that when HPMC is used in minute quantity it acts as channeling agent resulting in enhanced drug release rate.

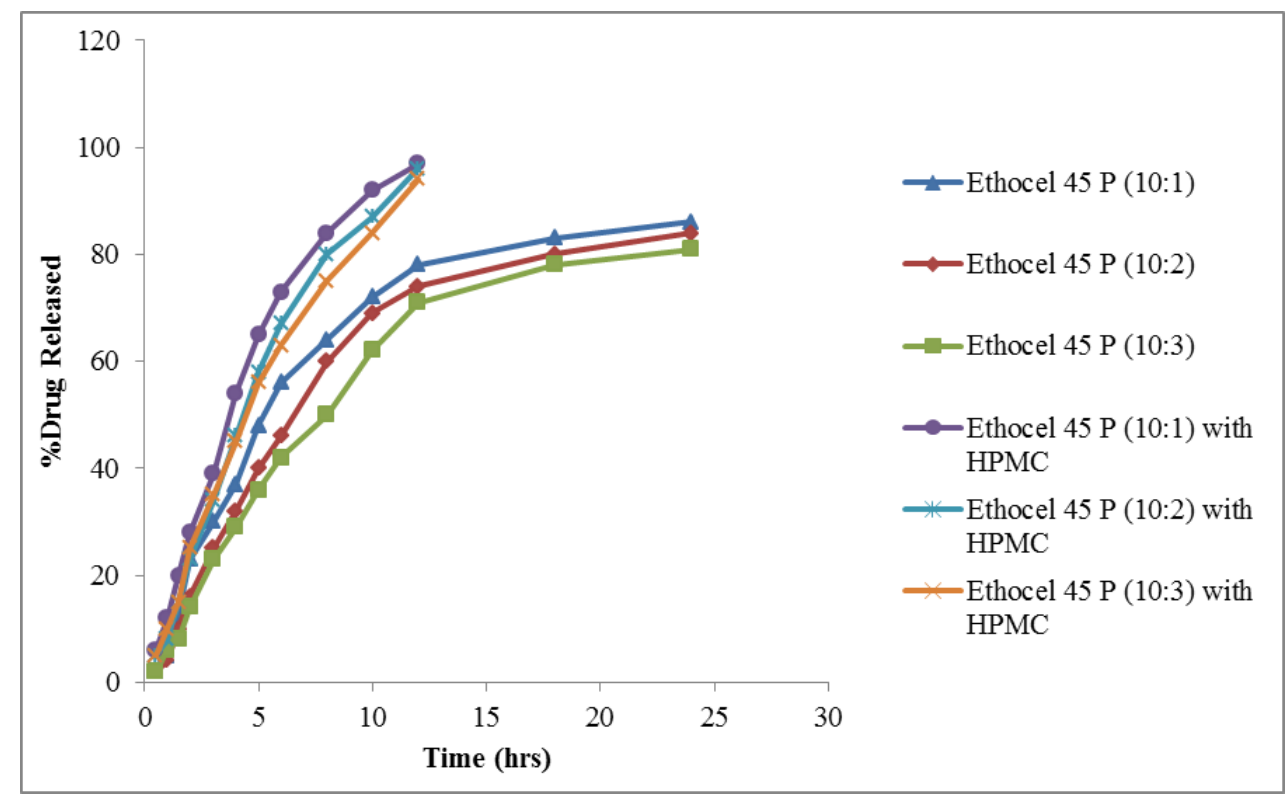

Fig. (5). Diltiazem Hydrochloride release from Ethocel 45 Premium matrices (10:1, 10:2 and 10:3) and Ethocel 45 Premium matrices (10:1, 10:2 and 10:3) matrices containing HPMC as co-excipient.

\subsection{Effect of CMC-Na}

Controlled release tablets with Ethocel Standard 45 Premium, 30\% of CMC were used in place of spray dried lactose. The respective drug release from controlled release matrices at D: P ratios of 10:1, 10:2, and 10:3 were 98\%, 
97\% and 95\% in 12 hours, as given in Fig. (6). CMC-Na breaks the polymeric membrane, therefore, increases the drug release and confirming the findings of other authors that $\mathrm{CMC}-\mathrm{Na}$ cause breakage of polymer membrane and enhances the drug release rates from polymeric matrices [17].

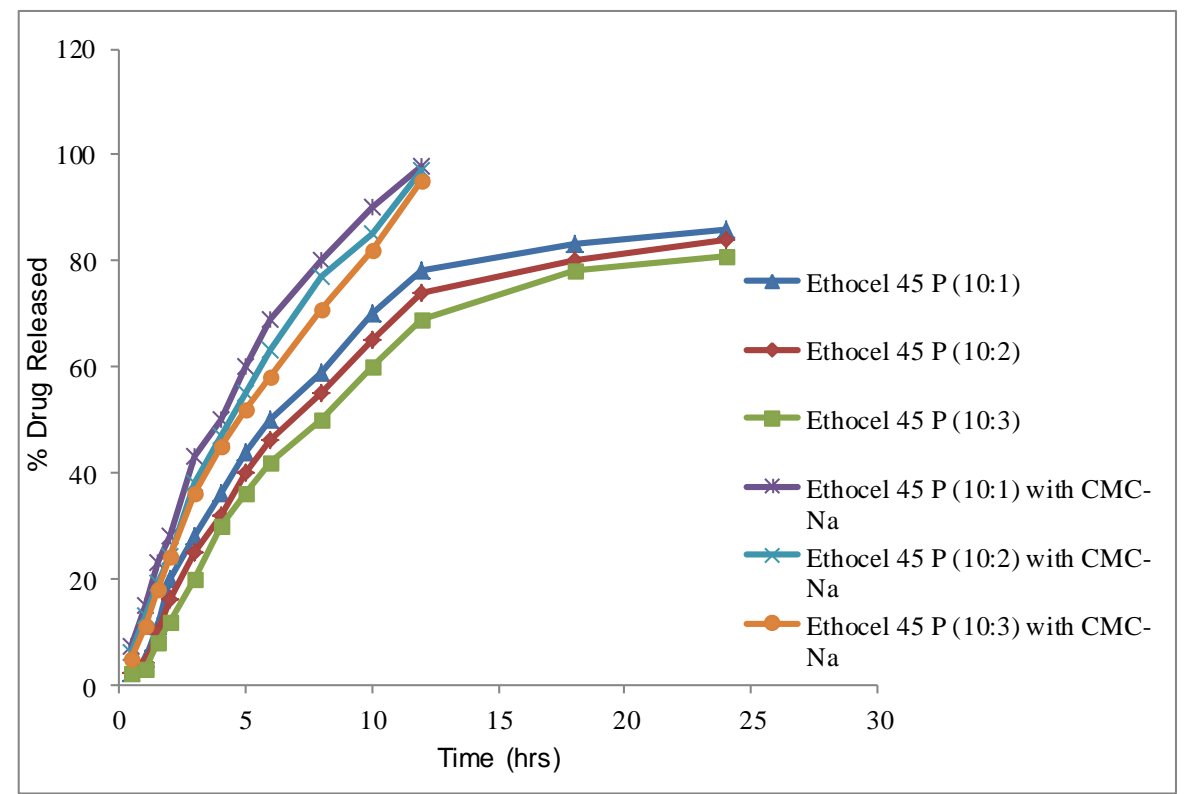

Fig. (6). Diltiazem Hydrochloride release from Ethocel 45 Premium matrices (10:1, 10:2 and 10:3) and Ethocel 45 Premium matrices (10:1, 10:2 and 10:3) matrices containing HPMC as co-excipient.

\subsection{Effect of Starch}

The controlled release matrices at D: P ratios of 10:1, 10:2, and 10:3 having Ethocel Standard 45 Premium with coexcipient starch (30\% of spray dried lactose) released $97 \%, 96 \%$ and $94 \%$ respectively in 10 hours (Fig. 7). Starch is a water soluble substance, if used in small amount; it acts as disintegrating agent because it swells up causing the breakage of polymeric membrane thereby enhancing the release of drug from matrices which is according to the findings [17] that the starch used as co-excipient causes disintegration and swelling with enhancement of the drug release rates.

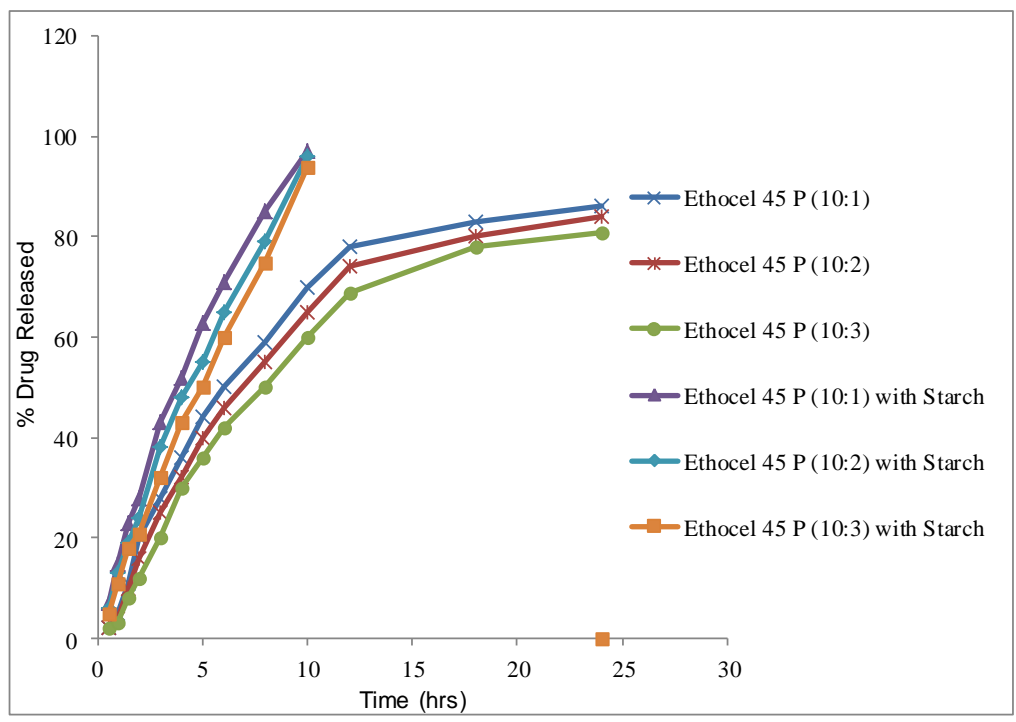

Fig. (7). Diltiazem Hydrochloride release from Ethocel 45 Premium matrices (10:1, 10:2 and 10:3) and Ethocel 45 Premium matrices (10:1, 10:2 and 10:3) matrices containing Starch as co-excipient. 


\subsection{Release Kinetics}

The drug release kinetics of controlled release matrices and matrices with co- excipients (starch or HPMC or CMC$\mathrm{Na}$ ) are given in the Tables 9, 10. Different kinetic models and in particular Korsmeyer Pappas model has given good results when the drug release data was fitted. The $\mathrm{n}$ (drug release exponent in Korsmeyer Pappas model) values of the matrices with polymer (Ethocel Standard 45 Premium) at D: P ratios of 10:1, 10:2 and 10:3 were 0.661, 0.673, and 0.689 respectively. The controlled release matrices with polymer (K100 LV Methocel) at D: P ratios of 10:1, 10:2 and $10: 3$ resultant $n$ values were $0.663,0.665$, and 0.678 , respectively. The $n$ values of the controlled release matrices with K15M EP Methocel Premium (D: P ratios of 10:1, 10:2 and 10:3) were 0.651, 0.633, and 0.649, respectively. These newly developed controlled release matrices released the drug by anomalous Fickian diffusion. Matrices with Ethocel Standard 45 Premium (D: P ratios of 10:1, 10:2 and 10:3) containing co-excipient HPMC, resultant $n$ values were $0.061,0.073$, and 0.098 respectively which show that these controlled release formulations do not follow the power law.

Table 9. Kinetic models parameters applied to release profiles of Diltiazem Hydrochloride controlled release matrices.

\begin{tabular}{|c|c|c|c|c|c|c|c|c|c|c|c|}
\hline \multirow{2}{*}{ Drug-to-Polymer Ratio } & \multicolumn{2}{|c|}{$W=k_{1} t$} & \multicolumn{2}{|c|}{$(100-w)=\ln 100-k_{2} t$} & \multicolumn{2}{|c|}{$(100-w)^{1 / 3}=100^{1 / 3}-k_{3} t$} & \multicolumn{2}{|c|}{$\mathbf{W}=\mathbf{k}_{\mathbf{4}} \mathbf{t}^{1 / 2}$} & \multicolumn{3}{|c|}{$\mathbf{M}_{\mathbf{t} /} \mathbf{M}_{\infty}=\mathbf{k}_{5} \mathbf{t}^{\mathrm{n}}$} \\
\hline & $\mathrm{k}_{1} \pm \mathrm{SD}$ & $\mathrm{r}_{1}$ & $\mathrm{k}_{2} \pm \mathrm{SD}$ & $\mathrm{r}_{2}$ & $\mathrm{k}_{3} \pm \mathrm{SD}$ & $\mathrm{r}_{3}$ & $\mathrm{k}_{4} \pm \mathrm{SD}$ & $\mathrm{r}_{4}$ & $\mathrm{k}_{5} \pm \mathrm{SD}$ & $\mathrm{r}$ & $\mathrm{n}$ \\
\hline \multicolumn{12}{|c|}{ Diltiazem Hydrochloride and Ethocel 45 Premium CR tablets } \\
\hline $10: 1$ & $7.21 \pm 0.231$ & 0.679 & $0.23 \pm 0.178$ & 0.981 & $0.57 \pm 0.098$ & 0.889 & $6.34 \pm 1.09$ & 0.985 & $0.01 \pm 0.231$ & 0.976 & 0.661 \\
\hline $10: 2$ & $6.35 \pm 0.298$ & 0.894 & $0.347 \pm 0.392$ & 0.916 & $0.641 \pm 0.132$ & 0.987 & $4.651 \pm 0.87$ & 0.981 & $0.31 \pm 1.541$ & 0.984 & 0.673 \\
\hline $10: 3$ & $5.325 \pm 0.123$ & 0.873 & $0.467 \pm 0.198$ & 0.987 & $0.923 \pm 2.45$ & 0.916 & $3.981 \pm 1.43$ & 0.992 & $0.478 \pm 0.98$ & 0.991 & 0.689 \\
\hline \multicolumn{12}{|c|}{ Diltiazem Hydrochloride and K100 LV Methocel } \\
\hline $10: 1$ & $6.32 \pm 0.213$ & 0.988 & $0.398 \pm 0.125$ & 0.214 & $0.87 \pm 0.891$ & 0.952 & $5.34 \pm 1.08$ & 0.989 & $0.01 \pm 0.251$ & 0.976 & 0.661 \\
\hline $10: 2$ & $7.453 \pm .098$ & 0.985 & $0.453 \pm .271$ & 0.876 & $0.45 \pm 0.09$ & 0.963 & $7.651 \pm 0.57$ & 0.985 & $0.21 \pm 1.571$ & 0.984 & 0.673 \\
\hline $10: 3$ & $6 \pm .143$ & 0.987 & $0.123 \pm .098$ & 0.983 & $0.543 \pm .097$ & 0.956 & $4.981 \pm 1.63$ & 0.991 & $0.178 \pm 0.982$ & 0.991 & 0.689 \\
\hline \multicolumn{12}{|c|}{ Diltiazem Hydrochloride and K15M EP Methocel Premium CR tablets } \\
\hline $10: 1$ & $5.123 \pm .09$ & 0.993 & $0.452 \pm 0.087$ & 0.981 & $0.872 \pm 0.791$ & 0.899 & $4.34 \pm 1.087$ & 0.965 & $0.01 \pm 0.241$ & 0.975 & 0.651 \\
\hline $10: 2$ & $6.51 \pm .087$ & 0.986 & $0.786 \pm 0.087$ & 0.986 & $0.452 \pm 0.19$ & 0.977 & $6.651 \pm 0.571$ & 0.951 & $0.11 \pm 1.571$ & \begin{tabular}{|l|}
0.983 \\
\end{tabular} & 0.633 \\
\hline $10: 3$ & $7.3 \pm .045$ & 0.991 & $0.53 \pm .123$ & 0.983 & $0.576 \pm .097$ & 0.976 & $5.981 \pm 1.632$ & 0.942 & $0.18 \pm 0.982$ & |0.961 & 0.649 \\
\hline
\end{tabular}

Table 10. Kinetic models parameters applied to release profiles of Diltiazem Hydrochloride Controlled Release Matrices with Co-excipients (HPMC, CMC-Na and Starch).

\begin{tabular}{|c|c|c|c|c|c|c|c|c|c|c|c|}
\hline \multirow{2}{*}{$\begin{array}{l}\text { Drug-to-Polymer } \\
\text { Ratio }\end{array}$} & \multicolumn{2}{|c|}{$\begin{array}{c}\mathrm{W}=\mathrm{k}_{\mathbf{1}} \mathbf{t} \\
\text { (Ist-order Kinetics) }\end{array}$} & \multicolumn{2}{|c|}{$\begin{array}{c}(100-w)=\ln 100-k_{2} t \\
(\text { Zero-order Kinetics) }\end{array}$} & \multicolumn{2}{|c|}{$\begin{array}{c}(100-w)^{1 / 3}=100^{1 / 3}-k_{3} t \\
(\text { Hixon Crowell Model) }\end{array}$} & \multicolumn{2}{|c|}{$\begin{array}{c}W=k_{4} t^{1 / 2} \\
\text { (Highuchi Model) }\end{array}$} & \multicolumn{3}{|c|}{$\begin{array}{l}\mathbf{M}_{\mathrm{t} /} \mathbf{M}_{\infty}=\mathbf{k}_{\mathbf{5}} \mathbf{t}^{\mathrm{n}} \\
\text { (Power Law) }\end{array}$} \\
\hline & $\mathrm{k}_{1} \pm \mathrm{SD}$ & $r_{1}$ & $\mathrm{k}_{2} \pm \mathrm{SD}$ & $\mathrm{r}_{2}$ & $\mathrm{k}_{3} \pm \mathrm{SD}$ & $r_{3}$ & $\mathrm{k}_{4} \pm \mathrm{SD}$ & $\mathrm{r}_{4}$ & $\mathrm{k}_{5} \pm \mathrm{SD}$ & $r_{5}$ & $\mathrm{n}$ \\
\hline \multicolumn{12}{|c|}{ Diltiazem Hydrochloride and Ethocel 45 Premium CR tablets containing HPMC as Co-excipient } \\
\hline 10: 1 & $4.21 \pm 0.231$ & 0.279 & $0.13 \pm 0.078$ & 0.581 & $0.37 \pm 0.078$ & 0.689 & $5.34 \pm 1.109$ & 0.385 & $0.01 \pm 0.031$ & 0.476 & 0.061 \\
\hline 10:2 & $5.35 \pm 0.298$ & 0.394 & $0.247 \pm 0.092$ & 0.516 & $0.441 \pm 0.032$ & 0.587 & $3.651 \pm 0.187$ & 0.481 & $0.11 \pm 1.341$ & 0.584 & 0.073 \\
\hline $10: 3$ & $3.325 \pm 0.123$ & 0.473 & $0.367 \pm 0.108$ & 0.487 & $0.623 \pm 1.45$ & 0.716 & $2.981 \pm 1.043$ & 0.692 & $0.278 \pm 0.918$ & 0.491 & 0.089 \\
\hline \multicolumn{12}{|c|}{ Diltiazem Hydrochloride and Ethocel 45 Premium CR tablets containing CMC-Na as Co-excipient } \\
\hline $10: 1$ & $4.354 \pm 0.213$ & 0.488 & $0.498 \pm 0.125$ & 0.314 & $0.67 \pm 0.891$ & 0.552 & $3.34 \pm 1.108$ & 0.489 & $0.02 \pm 0.451$ & 0.476 & 0.061 \\
\hline 10:2 & $3.43 \pm .098$ & 0.585 & $0.353 \pm .271$ & 0.376 & $0.55 \pm 0.09$ & 0.663 & $2.651 \pm 0.157$ & 0.585 & $0.021 \pm 2.571$ & 0.684 & 0.073 \\
\hline $10: 3$ & $4.5 \pm .143$ & 0.687 & $0.223 \pm .098$ & 0.483 & $0.643 \pm .097$ & 0.756 & $3.981 \pm 1.163$ & 0.491 & $0.078 \pm 1.982$ & 0.791 & 0.089 \\
\hline \multicolumn{12}{|c|}{ Diltiazem Hydrochloride and Ethocel 45 Premium CR tablets containing Starch as Co-excipient } \\
\hline 10:1 & $3.123 \pm .09$ & \begin{tabular}{|l|}
0.393 \\
\end{tabular} & $0.152 \pm 0.287$ & 0.281 & $0.672 \pm 0.791$ & 0.499 & $3.34 \pm 2.087$ & 0.565 & $0.03 \pm 2.241$ & 0.375 & 0.051 \\
\hline $10: 2$ & $2.51 \pm .087$ & 0.386 & $0.286 \pm 0.187$ & 0.486 & $0.352 \pm 0.19$ & 0.677 & $4.651 \pm 0.371$ & 0.651 & $0.21 \pm 4.571$ & 0.483 & 0.033 \\
\hline $10: 3$ & $4.3 \pm .045$ & 0.291 & $0.43 \pm .223$ & 0.383 & $0.476 \pm .097$ & 0.776 & $2.981 \pm 1.432$ & 0.442 & $0.08 \pm 0.582$ & 0.661 & 0.049 \\
\hline
\end{tabular}

\subsection{Results of Similarity Factor $\left(f_{2}\right)$ and Difference Factor $\left(f_{1}\right)$}

The similarity and difference between these polymer containing formulations in comparison with the reference standard was assessed by similarity factor $\left(f_{2}\right)$ and difference factor $\left(f_{1}\right)$. The results of $f_{2}$ values were less than 50 which indicate that none of the formulations were similar with the standard. The $f_{1}$ values were greater than 15 as given in 
Tables 11, 12. The acceptable ranges of $f_{1}$ and $f_{2}$ are 1-15 and 50-100 respectively [14]. These results are in conformity with other authors that controlled release matric of Flurbiprofen and Losartan Potassium based on polymer (Ethocel) was found to have differences in drug release profiles with reference standard formulations [18, 19].

\section{Table 11. Similarity factor $\left(f_{2}\right)$ values.}

\begin{tabular}{|c|c|}
\hline Reference Standard (Herbesser ${ }^{\boxplus}$ table)t $V s$ Test Formulations & $\mathbf{f}_{2}$ values \\
\hline Herbesser $^{\circledR}$ tablet/Diltiazem Hydrochloride and Ethocel 45Premium (10:1) & 38 \\
\hline Herbesser $^{\mathbb{Q}}$ tablet /Diltiazem Hydrochloride and Ethocel 45Premium (10:2) & 36 \\
\hline Herbesser $^{\circledR}$ tablet /Diltiazem Hydrochloride and Ethocel 45Premium (10:3) & 37 \\
\hline Herbesser $^{\circledR}$ tablet /Diltiazem Hydrochloride and K100 LV Methocel tablets (10:1) & 39 \\
\hline Herbesser $^{\mathbb{R}}$ tablet /Diltiazem Hydrochloride and K100 LV Methocel tablets (10:2) & 38 \\
\hline Herbesser $^{\mathbb{R}}$ tablet /Diltiazem Hydrochloride and K100 LV Methocel tablets (10:3) & 39 \\
\hline Herbesser $^{\circledR}$ tablet /Diltiazem Hydrochloride and K15M EP Methocel Premium tablets (10:1) & 35 \\
\hline Herbesser $^{\mathbb{B}}$ tablet /Diltiazem Hydrochloride and K15M EP Methocel Premium tablets (10:2) & 38 \\
\hline Herbesser $^{\mathbb{1}}$ tablet /Diltiazem Hydrochloride and K15M EP Methocel Premium tablets (10:3) & 34 \\
\hline Herbesser $^{\circledR}$ tablet /Diltiazem Hydrochloride and Ethocel 45Premium tablets (10:1) having Co-excipient (HPMC) & 28 \\
\hline Herbesser $^{\mathbb{(}}$ tablet /Diltiazem Hydrochloride and Ethocel 45Premium tablets (10:2) having Co-excipient (HPMC) & 29 \\
\hline Herbesser $^{\mathbb{R}}$ tablet /Diltiazem Hydrochloride and Ethocel 45Premium tablets (10:3) having Co-excipient (HPMC) & 26 \\
\hline Herbesser $^{\mathbb{B}}$ tablet /Diltiazem Hydrochloride and Ethocel 45Premium tablets (10:1) having Co-excipient (CMC-Na) & 27 \\
\hline Herbesser $^{\mathbb{6}}$ tablet /Diltiazem Hydrochloride and Ethocel 45Premium tablets (10:2) having Co-excipient (CMC-Na) & 25 \\
\hline Herbesser $^{\mathbb{B}}$ tablet /Diltiazem Hydrochloride and Ethocel 45Premium tablets (10:3) having Co-excipient (CMC-Na) & 30 \\
\hline Herbesser $^{\mathbb{B}}$ tablet /Diltiazem Hydrochloride and Ethocel 45Premium tablets (10:1) having Co-excipient (Starch) & 32 \\
\hline Herbesser $^{\mathbb{Q}}$ tablet /Diltiazem Hydrochloride and Ethocel 45Premium tablets (10:2) having Co-excipient (Starch) & 29 \\
\hline Herbesser $^{\mathbb{\oplus}}$ tablet /Diltiazem Hydrochloride and Ethocel 45Premium tablets (10:3) having Co-excipient (Starch) & 30 \\
\hline
\end{tabular}

Table 12. Difference factor $\left(f_{1}\right)$ values.

\begin{tabular}{|c|c|}
\hline Reference Standard (Herbesser ${ }^{\circledR}$ table)t $V s$ Test Formulations & Difference factor $\left(f_{1}\right)$ values \\
\hline 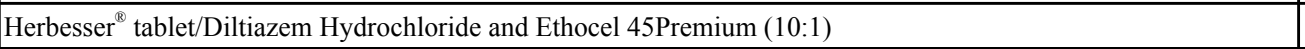 & 65 \\
\hline Herbesser ${ }^{\circledR}$ tablet /Diltiazem Hydrochloride and Ethocel 45Premium (10:2) & 62 \\
\hline Herbesser $^{\circledR}$ tablet /Diltiazem Hydrochloride and Ethocel 45Premium (10:3) & 67 \\
\hline Herbesser $^{\mathbb{B}}$ tablet /Diltiazem Hydrochloride and K100 LV Methocel tablets (10:1) & 70 \\
\hline Herbesser $^{\circledR}$ tablet /Diltiazem Hydrochloride and K100 LV Methocel tablets (10:2) & 65 \\
\hline Herbesser $^{\circledR}$ tablet /Diltiazem Hydrochloride and K100 LV Methocel tablets (10:3) & 72 \\
\hline Herbesser $^{\circledR}$ tablet /Diltiazem Hydrochloride and K15M EP Methocel Premium tablets (10:1) & 70 \\
\hline Herbesser $^{\circledR}$ tablet /Diltiazem Hydrochloride and K15M EP Methocel Premium tablets (10:2) & 68 \\
\hline Herbesser $^{\circledR}$ tablet /Diltiazem Hydrochloride and K15M EP Methocel Premium tablets (10:3) & 65 \\
\hline Herbesser $^{\mathbb{B}}$ tablet /Diltiazem Hydrochloride and Ethocel 45Premium tablets (10:1) having Co-excipient (HPMC) & 34 \\
\hline Herbesser $^{\circledR}$ tablet /Diltiazem Hydrochloride and Ethocel 45Premium tablets (10:2) having Co-excipient (HPMC) & 32 \\
\hline Herbesser $^{\circledR}$ tablet /Diltiazem Hydrochloride and Ethocel 45Premium tablets (10:3) having Co-excipient (HPMC) & 35 \\
\hline Herbesser $^{\circledR}$ tablet /Diltiazem Hydrochloride and Ethocel 45Premium tablets (10:1) having Co-excipient (CMC-Na) & 33 \\
\hline Herbesser $^{\circledR}$ tablet /Diltiazem Hydrochloride and Ethocel 45Premium tablets (10:2) having Co-excipient (CMC-Na) & 31 \\
\hline Herbesser $^{\circledR}$ tablet /Diltiazem Hydrochloride and Ethocel 45Premium tablets (10:3) having Co-excipient (CMC-Na) & 35 \\
\hline Herbesser $^{\circledR}$ tablet /Diltiazem Hydrochloride and Ethocel 45Premium tablets (10:1) having Co-excipient (Starch) & 37 \\
\hline Herbesser $^{\circledR}$ tablet /Diltiazem Hydrochloride and Ethocel 45Premium tablets (10:2) having Co-excipient (Starch) & 34 \\
\hline Herbesser $^{\mathbb{B}}$ tablet /Diltiazem Hydrochloride and Ethocel 45Premium tablets (10:3) having Co-excipient (Starch) & 32 \\
\hline
\end{tabular}

\section{CONCLUSION}

As a result of this study it is concluded that these polymers can be used for the development of CR matrices of water soluble drugs like Diltiazem Hydrochloride. These polymers act as enhancer of drug release kinetics considerably as 
compared to the conventional formulations (Herbesser ${ }^{\circledR}$ tablets). The co-excipients also increased the drug release rates when added into the matrices irrespective of the solubility profile of the active ingredient. Majority of the formulations followed the anomalous non Fickian diffusion while the formulations with co-excipients did not abide the power law. The $f_{2}$ and $f_{1}$ values were not present in the respective ranges. Controlled release matrices of Diltiazem Hydrochloride with the polymers used in this study may decrease the dosage frequency thereby increasing the patient compliance.

\section{CONFLICT OF INTEREST}

The authors confirm that this article content has no conflict of interest.

\section{ACKNOWLEDGEMENTS}

Declared none.

\section{REFERENCES}

[1] Pillai, O.; Dhanikula, A.B.; Panchagnula, R. Polymers in drug delivery. Curr. Opin. Chem. Biol., 2001, 5, 439-446.

[2] Robinson, J.R. Sustained and controlled release drug delivery systems. Drugs and Pharmaceutical Sciences. Marcel Dekker: New York. NY, 1978; 6, pp. 773-774.

[3] Kumar, R.M. Nano and microparticles as controlled drug delivery devices. J. Pharm. Pharm. Sci., 2000, 3, 234-258. [PMID: 10994037]

[4] Li, V.H.K.; Robinson, J.R.; Lee, V.H.L. Controlled Drug Delivery: Fundamentals and Applications. Marcel Dekker: Inc., NY, 1987; 29 , p. 7.

[5] Opie, L.H.; Messerli, F.H. Nifedipine and mortality. Grave defects in the dossier. Circulation, 1995, 92(5), $1068-1073$. [http://dx.doi.org/10.1161/01.CIR.92.5.1068] [PMID: 7648646]

[6] Chowdary, K.P.R.; Satyanarayana, K.V.; Kumar, D.S.S.; Priya, Y.D.G. Preparation and evaluation of controlled release diltiazem hcl tablets by using ethyl cellulose and ethylene-vinyl acetate polymers as retardant Int. J. Pharm., 2011, 1(1), 34-39.

[7] Shah, S.; Khan, G.M.; Jan, S.U.; Shah, K.; Hussain, A.; Khan, H.; Khan, H.; Khan, H.; Khan, K.A. Development of novel diclofenac potassium controlled release tablets by wet granulation technique and the effect of co-excipients on in vitro drug release rates. Pak. J. Pharm. Sci., 2012, 25(1), 161-168.

[PMID: 22186325]

[8] Zsotér, T.T.; Church, J.G. Calcium antagonists. Pharmacodynamic effects and mechanism of action. Drugs, 1983, 25(2), 93-112. [http://dx.doi.org/10.2165/00003495-198325020-00001] [PMID: 6131809]

[9] Xu, G.; Sunada, H. Influence of formulation change on drug release kinetics from hydroxypropylmethylcellulose matrix tablets. Chem. Pharm. Bull. (Tokyo), 1995, 43(3), 483-487. [http://dx.doi.org/10.1248/cpb.43.483] [PMID: 7774032]

[10] Higuchi, T.; Connors, K.A. Phase solubility techniques Adv. Anal. Chem. Instrum., 1965, 4, 117.

[11] Ritger, R.L.; Peppas, N.S. A simple equation for description of solute release II. Fickian and anomalous release from swellable devices. J. Control. Release, 1987, 5, 37-42.

[http://dx.doi.org/10.1016/0168-3659(87)90035-6]

[12] Gohal, M.C.; Panchal, M.K. Novel use of similarity factors $\mathrm{f} 2$ and Sd for the development of diltiazem HCl modified-release tablets using a 3(2) factorial design. Drug Dev. Ind. Pharm., 2002, 28, 77-87. [http://dx.doi.org/10.1081/DDC-120001488] [PMID: 11858527]

[13] Khan, G.M.; Meidan, V.M. Drug release kinetics from tablet matrices based upon ethylcellulose ether-derivatives: a comparison between different formulations. Drug Dev. Ind. Pharm., 2007, 33(6), 627-639. [http://dx.doi.org/10.1080/03639040601179954] [PMID: 17613027]

[14] Gohal, M.C.; Patel, T.P.; Bariyah, S.H. Studies in preparation and evaluation of pH-independent sustained-release matrix tablets of verapamil $\mathrm{HCl}$ using directly compressible Eudragits. Pharm. Dev. Technol., 2003, 8, 323-333. [http://dx.doi.org/10.1081/PDT-120024686] [PMID: 14601957]

[15] Khan, G.M.; Zhu, J.B. Formulation and in vitro evaluation of ibuprofen-carbopol ${ }^{\circledR}$ 974P-NF controlled release matrix tablets III: influence of co-excipients on release rate of the drug. J. Contr. Rel., 1998, 54(2), 185-190. [http://dx.doi.org/10.1016/S0168-3659(97)00225-3]

[16] Ford, J.L.; Rubinstein, M.H.; McCaul, F.; Hogan, J.E.; Edgar, P.J. Importance of drug type, tablet shape and added diluents on drug release kinetics from hydroxypropylmethylcellulose matrix tablets. Int. J. Pharm., 1987, 40, 223-234. [http://dx.doi.org/10.1016/0378-5173(87)90172-4]

[17] Alderman, D.A. A review of cellulose ethers in hydrophilic matrices for oral controlled-release dosage forms. Int. J. Pharm. Technol., 1984, $5,1-9$.

[18] Khan, K.A.; Khan, G.M.; Shah, K.U.; Shah, S.U.; Mehsud, S.U.; Rehman, A. Studies on Drug release kinetics of Controlled Released matrices of Flubiprofen and Comparison with market product. Lat. Americ. J. Pharm., 2013, 32(9), 1321-1328. 
[19] Khan, K.A.; Khan, G.M.; Zeeshan Danish, M.; Akhlaq, H.; Khan, H.; Rehman, F.; Mehsud, S. Formulation and in vitro evaluation of directly compressed controlled release matrices of Losartan Potassium using Ethocel Grade 100 as rate retarding agent. Int. J. Pharm., 2015, 496(2), 759-765.

[http://dx.doi.org/10.1016/j.ijpharm.2015.10.051] [PMID: 26545310]

(C) Razaque et al.; Licensee Bentham Open.

This is an open access article licensed under the terms of the Creative Commons Attribution-Non-Commercial 4.0 International Public License (CC BY-NC 4.0) (https://creativecommons.org/licenses/by-nc/4.0/legalcode), which permits unrestricted, non-commercial use, distribution and reproduction in any medium, provided the work is properly cited. 